\title{
Comparison of General Anesthesia with Spinal Anesthesia in Laparoscopic Cholecystectomy Operations
}

\author{
Laparoskopik Kolesistektomi Ameliyatlarında Genel Anestezi ile \\ Spinal Anestezinin Karşılaştırılması
}

\section{Alperen KISA $\odot$, Senem KORUK๑, Hasan KOCOGLU ๑, İhsan Metin LEBLEBICI $\odot$}

Ethics Committee Approval: This study was approved by the Istanbul Medeniyet University Goztepe Training and Research Hospital,Clinical Studies Ethics Committee, 30 December 2016, 2016/0223.

Conflict of interest: The authors declare that they have no conflict of interest.

Funding: None.

Informed Consent: Informed consent was taken from the patients enrolled in this study
Cite as: Kısa A, Koruk S, Kocoglu H, Leblebici M. Comparison of general anesthesia with spinal anesthesia in laparoscopic cholecystectomy operations. Medeniyet Med J. 2019:34:346-53.

\begin{abstract}
Objective: Laparoscopic cholecystectomy (LC) operations are being performed under general anesthesia $(G A)$. Further studies are needed on the issue whether these operations can be performed under spinal anesthesia (SA). In this study we aimed to compare $S A$ with (GA) in terms of efficacy and complications in patients who will undergo LC operations, and to investigate the effects of preemptive analgesia on the development of shoulder pain, transition to general anesthesia, and postoperative analgesia.

Method: Sixty patients in ASA I-II risk group between 18-65 years of age undergoing laparoscopic cholecystectomy were randomly divided into general anesthesia $(G A, n=30)$ and spinal anesthesia $(S A, n=30)$ groups. Patients were premedicated with i.v. midazolam and fentanyl preoperatively. Anesthesia was induced with propofol in the GA group, and maintained with Desflurane and remifentanil. In the SA group, spinal anesthesia was provided with intratechal administration of $15 \mathrm{mg}$ bupivacaine at L2-3 level, and block level was increased to T4 by keeping the patient in Trendelenburg position for 7-10 minutes. Demographic data, hemodynamic parameters, operation time, visual analog scale (VAS) scores at postoperative $0^{\text {th }}, 1^{\text {st }}, 4^{\text {th }}, 8^{\text {th }}, 12^{\text {th }}$ and $24^{\text {th }}$ hours, patient-surgeon satisfaction, side effects, and occurrence of right shoulder pain in SA group were inquired and recorded.

Results: Effective anesthesia was produced in both groups. Hypotension was observed in 5, bradycardia requiring atropin administration in 4, and perioperative shoulder pain in 9 patients in Group SA, but none of them required general anesthesia. Hypotension developed in one patient in Group GA. The postoperative VAS scores were significantly lower in Group SA at $O^{\text {th }}, 1^{\text {st }}, 4^{\text {th }}$ hours. Patient satisfection scores were higher in Group SA.

Conclusion: We concluded that spinal anesthesia may be an alternative method to general anesthesia in patients who will undergo laparoscopic cholecystectomy operations especially when the risk of general anesthesia is too high.
\end{abstract}

Keywords: Laparoscopic cholecystectomy, general anesthesia, spinal anesthesia, surgeon satisfaction, postoperative pain

öz

Amac: Laparoskopik kolesistektomi (LK) operasyonları yaygın olarak genel anestezi altında uygulanmaktadır Spinal anestezi ile bu operasyonların yapılıp yapılamayacağı konusunda daha fazla çalışmaya ihtiyaç bulunmaktadır. Bu çalışmada $L K$ geçirecek olgularda genel anestezi ile spinal anestezinin etkinlik ve komplikasyonlar açısından karşılaştııılması ve uygulanan preemptif analjezinin omuz ağrısı gelişimi, genel anesteziye geçiş oranı ve postoperatif analjezi üzerine olan etkilerinin arastırılması amaclanmıstır.

Yöntem: Laparoskopik kolesistektomi uygulanacak 18-65 yaşları arasında, ASA I-II risk grubunda 60 hasta, rastgele, genel anestezi (Grup $G A, n=30$ ) ve spinal anestezi (Grup $S A, n=30$ ) olarak iki gruba ayrild. Her iki grupta operasyondan önce i.v. midazolam ve fentanil ile premedikasyon yapıldı. GA grubunda propofol ile anestezi indüksiyon sonrası desfluran ve remifentanil ile idame sağlandı. SA grubunda hastalara L2-3 aralığından girilerek $15 \mathrm{mg}$ bupivakain ile spinal anestezi sağlanmasını takiben 7-10 dk. Trendelenburg pozisyonunda tutularak blok seviyesinin T4 düzeyine çıkması sağlandı. Demografik veriler, hemodinamik parametreler, operasyon süresi, postoperatif $0 ., 1$., 4., 8., 12. ve 24. saat görsel analog skala (VAS) skorları, hasta-cerrah memnuniyeti ve yan etkiler kaydedilerek karsılastırıldı. SA grubunda perioperatif sağ omuz ağrısı sorgulanarak kaydedildi.

Bulgular: Grup SA'da 5 hastada hipotansiyon, 4 hastada atropin gerektiren bradikardi, 9 hastada perioperatif omuz ağrısı gözlendi. Hiçbir hastada genel anesteziye geçilmedi. Grup GA'da 1 hastada hipotansiyon gelişti. Postoperatif VAS skorları O., 1. ve 4. saatlerde Grup SA'da anlamlı olarak düsük bulundu. Hasta memnuniyet skorları Grup SA'da yüksek bulundu.

Sonuç: Laparoskopik kolesistektomi geçirecek hastalarda, özellikle genel anestezi riskinin yüksek olduğu durumlarda, spinal anestezinin genel anesteziye alternatif bir yöntem olabileceği kanısına varılmıstıtı.

Anahtar kelimeler: Laparoskopik kolesistektomi, genel anestezi, spinal anestezi, cerrah memnuniyeti, postoperatif ağrı

() Copyright Istanbul Medeniyet University Faculty of Medicine. This journal is published by Logos Medical Publishing.

Licenced by Creative Commons Attribution-NonCommercial 4.0 International (CC BY-NC 4.0)
Received: 20 November 2019

Accepted: 06 December 2019

Online First: 26 December 2019

Corresponding Author:

S. Koruk

ORCID: 0000-0003-1795-150X

Istanbul Medeniyet University,

Goztepe Training and Research

Hospital, Department of

Anesthesiology and Reanimation, Istanbul, Turkey

senem_koruk@yahoo.com

A. Kisa

ORCID: 0000-0003-3699-2032

Hitit University Erol Olcok Education and Research Hospital,

Department Anesthesiology and

Reanimation,

Istanbul, Turkey

H. Kocoglu

ORCID: 0000-0002-0363-9307

Istanbul Medeniyet University,

Goztepe Training and Research

Hospital, Department of

Anesthesiology and Reanimation, Istanbul, Turkey

i.M. Leblebici

ORCID: 0000-0002-1403-7643 Istanbul Medeniyet University, Goztepe Training and Research Hospital, Department of General Surgery, Istanbul, Turkey 


\section{INTRODUCTION}

Laparoscopy has been used in cholecystectomy operations since 1988 in patients with symptomatic cholelithiasis, and has been the first choice of surgical method with time. This technique has been preferred because of its less invasiveness, shorter hospital stay and shorter return to daily activities, and reduced postoperative pain ${ }^{1}$. While laparoscopic cases are traditionally performed under general anesthesia recent studies have shown that neuroaxial blocks may be good alternatives in these surgeries ${ }^{2}$. Studies have reported that achievement of anesthesia between T4 to T6 level in neuroaxial blocks is sufficient for these operations $^{3,4}$. In addition spinal anesthesia has been shown to yield more favourable outcomes than general anesthesia in terms of postoperative pain, complications, and procedural costs ${ }^{5,6}$. However, during pneumoperitoneum in patients having spinal anesthesia some side effects are encountered related to insufflations of the abdominal cavity. The shoulder pain is one of these complications which is caused by the irritation of the subdiaphragmatic area with $\mathrm{CO}_{2}$, and reported to be seen in $25 \%$ of laparoscopic cases performed under spinal anesthesia. This area is innervated by phrenic nerve originating from $3^{\text {rd }}$ to $5^{\text {th }}$ cervical nerve roots. Normally this level is not blocked, and the pain can not be prevented in conventional spinal anesthesia applications ${ }^{7}$. Postoperative pain is another problem in these patients. The cause of this pain is multifactorial but the visceral pain is prominent. Preemptive analgesia can be provided by reducing central sensitization of noxious stimuli by spinal anesthesia. The transition to general anesthesia was reported to be inevitable in $3.4 \%$ of the cases. However, studies about the effects of spinal anesthesia in cholecystectomy operations have not yielded satisfactory results yet.

In this study we aimed to compare the effectiveness of spinal anesthesia with that of general anesthesia in laparoscopic cholecystectomy operations, and to evaluate the effects of preemptive analgesia on the development of shoulder pain, on the rate of transition to general anesthesia, and on postoperative analgesia.

\section{MATERIALS and METHODS}

This study approved by the Istanbul Medeniyet University Goztepe Training and Research Hospital, Clinical Studies Ethics Committee, on December 30 2016, with decision number 2016/0223. Informed consent was taken from the patients enrolled in this study.

Sixty patients in ASA I and II risk groups aging between 18-65 years and undergoing elective laparoscopic cholecystectomy were included in the study. Patients in ASA III risk group or above, and over 65 or under 18 years of age, with local anesthetic or opioid allergy, active infection or abnormal coagulation tests, who were contraindicated for spinal anesthesia, and those who could not be cooperated were excluded from the study. We randomly divided the patients into two groups as spinal anesthesia (Group SA, $\mathrm{n}=30$ ) and general anesthesia (Group GA, $n=30$ ) groups using computer generated random list. The cardiac rhythm, heart rate (HR), noninvasive blood pressure [(systolic (SAP), diastolic (DAP), mean arterial pressure (MAP)], and peripheral oxygen saturation $\left(\mathrm{SpO}_{2}\right)$ were monitored. Patients were premedicated with midazolam (25-30 $\mu \mathrm{g} / \mathrm{kg}$ IV) in group GA after intravenous catheter insertion. Then, we used $2-2.5 \mathrm{mg} / \mathrm{kg}$ propofol and $0.6 \mathrm{mg} / \mathrm{kg}$ rocuronium bromide i.v. for anesthetic induction after preoxygenation with $100 \% \mathrm{O}_{2}$ for 2-3 minutes. Patients were ventilated with a tidal volume of $7 \mathrm{ml} / \mathrm{kg}$ and a frequency of $12 / \mathrm{min}$. General anesthesia was maintained with $50 \% \mathrm{O}_{2} /$ air mixture in 5-6\% desflurane and remifentanil i.v. infusion at a dose of $0.5 \mu \mathrm{g} / \mathrm{kg} / \mathrm{min}$. For spinal anesthesia group; after proper positioning, $15 \mathrm{mg}$ Bupivacaine were injected into the subarachnoid space from the L2-3 level with $25 \mathrm{G}$ pencil-point spinal needle (Egemen International, Izmir, Turkey) under sterile conditions. The patients were placed in the su- 
pine and at 15-30 degree head down position for about 7-10 minutes, and the analgesia level was expected to rise to $\mathrm{T} 4$ level in the control with a pinprick test. The patient was then placed in a light head-up position, and sedation with 25-30 $\mu \mathrm{g} / \mathrm{kg}$ i.v. midazolam, and $1 \mu \mathrm{g} / \mathrm{kg}$ fentanyl i.v. was performed as preemptive analgesia, and surgical procedure was started. Ephedrine $(10 \mathrm{mg})$ was planned to be given in case of hypotension (MAP <60 $\mathrm{mmHg}$ ), and repeated after 5 minutes if it persists. Atropine sulphate $(0.5 \mathrm{mg}$ i.v.) was planned to be given in case of bradycardia (HR $<40$ bpm). Age, gender, ASA risk group, operation time, ephedrine and atropine consumption were recorded. Hemodynamic measurements (SAP, DAP and MAP), oxygen saturation, side effects, and shoulder pain were recorded prior to the procedure (after intubation in Group GA and after drug administration in Group SA) and at 5-minute intervals during the operation. In case of shoulder pain additional fentanyl $1 \mu \mathrm{gr} / \mathrm{kg}$ was planned to be given intravenously, and the response was recorded.

In patients having spinal anesthesia the need for nasogastric catheterization, the development of organ damage, hemorrhage or shoulder pain, and lack of response despite the addition of fentanyl were considered as the indication for a transition to general anesthesia. Tramadol $1.5 \mathrm{mg} / \mathrm{kg}$ i.v. and metoclopramide i.v. were administered to general anesthesia group patients 10 minutes before the end of surgery. Visual analogue scale (VAS) scores were recorded at the postoperative $0^{\text {th }}, 1^{\text {st }}$, $4^{\text {th }}, 8^{\text {th }}, 12^{\text {th }}$ and $24^{\text {th }}$ hours in both groups. In the postoperative period tenoxicam i.v. (Oksamen-L 20 mg, Mustafa Nevzat Pharmaceuticals, Istanbul, Turkey) was administered as analgesic drug to patients with VAS values above 4 in both groups. Patients were followed up for the development of postoperative nausea and vomiting (PONV). Since urinary retention was expected after spinal anesthesia, the patients in Group SA were followed up for this complication during postoperative period. For the measurement of patient sat- isfaction at the postoperative $24^{\text {th }}$ hour, patients in both groups were asked to score the satisfaction level between 0 and 10 in terms of anesthetic technique. The surgeons were also asked to give a score between 0 and 10 for each group in terms of the surgical procedure and comfort, and the both of the scores of the surgeons and patients were recorded.

For statistical analysis, NCSS (Number Cruncher Statistical System) 2007 (Kaysville, Utah, USA) program was used. In the study data, using descriptive statistical methods (mean, standard deviation, median, frequency, ratio, minimum, maximum) quantitative data were compared. For the comparison of the parameters showing normal distribution we used "Student t-Test", and Mann Whitney U par test was used for the comparison of the parameters with non-normal distribution. Pearson's chi-Square test and Fisher's exact test were used to compare qualitative data. For intragroup pairwise comparisons of non-normally distributed parameters, "Friedman Test" and "Wilcoxon Signed Ranks" test were used. According to the post-hoc analysis based on the $4^{\text {th }}$ hour VAS values, the effect size was calculated as 1.897 , and statistical power as 100\% (Open Epi Version 3). Significance was set at $\mathrm{P}<0.05$.

\section{RESULTS}

There was no statistically significant difference between groups in terms of age, ASA scores, and operation times $(p>0.05)$. Male/female ratio in spinal anesthesia group, but female/male ratio in general anesthesia group were found to be significantly higher (Table 1 ). There was a statistically significant difference between Groups GA and SA in terms of body weight (BW) which was significantly higher in Group SA ( $p=0.048)$. However, since the difference between the values was less than $10 \%$ and $p$ value was close to the threshold, intergroup difference was considered as clinically insignificant. 
Table 1. Demographic data.

\begin{tabular}{|c|c|c|c|c|}
\hline & & $\begin{array}{l}\text { Group SA } \\
(n=30)\end{array}$ & $\begin{array}{l}\text { Group GA } \\
(n=30)\end{array}$ & $\begin{array}{l}\mathbf{p} \\
\text { Value }\end{array}$ \\
\hline Age (year) & $\begin{array}{l}\text { Min-Max } \\
\text { (Median) } \\
\text { Mean } \pm \text { SD }\end{array}$ & $\begin{array}{l}19-65(51.5) \\
48.33 \pm 13.62\end{array}$ & $\begin{array}{l}22-65(50) \\
47.13 \pm 12.35\end{array}$ & ${ }^{\mathrm{a}} 0.620$ \\
\hline Gender (\%) & $\begin{array}{l}\text { Female } \\
\text { Male }\end{array}$ & $\begin{array}{l}17(41.5) \\
13(68.4)\end{array}$ & $\begin{array}{l}24(58.5) \\
6(31.6)\end{array}$ & b0.042* \\
\hline $\begin{array}{l}\text { Body } \\
\text { weight (kg) }\end{array}$ & $\begin{array}{l}\text { Min-Max } \\
\text { (Median) } \\
\text { Mean } \pm \text { SD }\end{array}$ & $\begin{array}{l}68-103(79.5) \\
82.03 \pm 10.15\end{array}$ & $\begin{array}{l}65-98(73) \\
77.33 \pm 9.64\end{array}$ & a $0.043^{*}$ \\
\hline $\begin{array}{l}\text { ASA } \\
\text { n (\%) }\end{array}$ & $\begin{array}{l}\text { I } \\
\text { II }\end{array}$ & $\begin{array}{l}16(45.7) \\
14(56.0)\end{array}$ & $\begin{array}{l}19(54.3) \\
11(44.0)\end{array}$ & ${ }^{\mathrm{b}} 0.432$ \\
\hline $\begin{array}{l}\text { Operation } \\
\text { time } \\
\text { (minutes) }\end{array}$ & $\begin{array}{l}\text { Min-Max } \\
\text { (Median) } \\
\text { Mean } \pm \text { SD }\end{array}$ & $\begin{array}{l}20-80(42.5) \\
43.67 \pm 12.73\end{array}$ & $\begin{array}{l}20-130(45) \\
48.33 \pm 26.31\end{array}$ & ${ }^{\mathrm{a}} 0.982$ \\
\hline
\end{tabular}

a Mann Whitney U Test, ${ }^{b}$ Pearson Chi-Square Test, * $p<0.05$ Group SA: Group Spinal Anesthesia, Group GA: Group General Anesthesia ASA: American Society of Anesthesiology

At baseline and 5th min. after the procedure (induction in the general anesthesia group, and after the block in spinal anesthesia group) there was no statistically significant difference between the groups in HR values, but in the spinal anesthesia group the HR values at $10^{\text {th }}$ min $(p=0.002)$, $15^{\text {th }} \min (p=0.007), 20^{\text {th }} \min (p=0.020)$, and $25^{\text {th }}$ $\min (p=0.044)$ after the procedure were significantly lower than Group GA. The HR in group SA was significantly higher than that of Group GA at $45^{\text {th }}$ minute after the procedure $(p=0.011)$. Heart rates were found to be lower in the spinal anesthesia group at $10^{\text {th }}, 15^{\text {th }}$ and $20^{\text {th }}$ minutes after the procedure compared to the initial values ( $p$ values respectively $p=0.005, p=0.038, p=0.002$ ). No statistically significant difference was found between the groups in terms of changes in the HR values before during and after pneumoperitoneum $(p>0.05)$.

After spinal anesthesia, MAP values were lower in the Group SA in between postoperative $15^{\text {th }}$ $(p=0.025)$ and $20^{\text {th }}-45^{\text {th }}$ minutes $(p<0.001)$ compared to the Group GA. Significant decreases in MAP values between $5^{\text {th }}$ and $20^{\text {th }}$ minutes were recorded in Group SA compared to baseline. Significant decreases were also noted in MAP values during and after pneumoperitoneum compared to pre-pneumoperitoneum in Group SA. There was a significant intragroup decrease in MAP at the $5^{\text {th }}, 10^{\text {th }}$ and $20^{\text {th }}$ min. in Group GA compared to the baseline values ( $p$ values respectively $p=0.002, p=0.036$ and $p=0.04$ ). Similarly, blood pressures during pneumoperitoneum were significantly lower than those measured before and after pneumoperitoneum in Group GA ( $p=0.018)$. The decrease in MAP values after pneumoperitoneum compared to pre-pneumoperitoneum period in spinal anesthesia group were found to be greater than that of general anesthesia group $(p=0.018)$ (Figure 1).

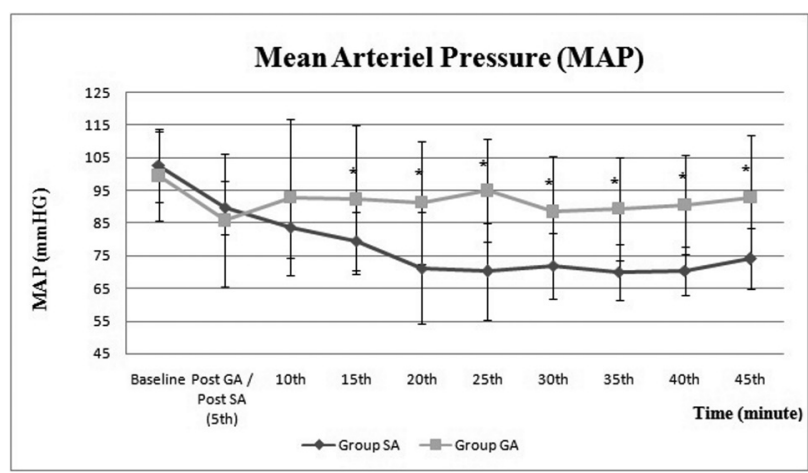

${ }^{*} p<0.05$ considered statistically significant

Figure 1. Changes in mean arterial blood pressure values in two groups.

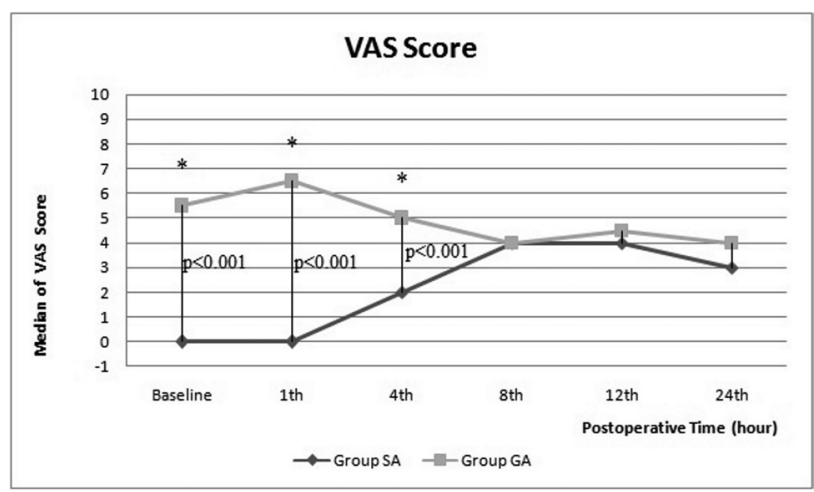

${ }^{*} p<0.05$ considered statistically significant

Figure 2. Changes in visual analogue scale (VAS) values in two groups. 
VAS scores in Group SA were lower in the first four hour than that of general anesthesia group $(p<0.001)$. There was no statistically significant difference between the groups in VAS scores at $8^{\text {th }}, 12^{\text {th }}$ and $24^{\text {th }}$ hours postoperatively (Figure 2 ). No statistically significant difference was found in VAS scores between the genders at any measurement time ( $p>0.05)$. There was no difference between the groups in terms of surgical satisfaction scores. Patient satisfaction scores were found to be higher in spinal anesthesia group $(p<0.001$, Table 2). Shoulder pain was observed in 9 patients (30\%) in Group SA. Atropine was given to four patients (13.3\%) in Group SA, and not needed in any patient in Group GA ( $>>0.05)$. However, there was a statistically significant difference between the groups regarding the use of ephedrine $150 \%$ in SA group and $3.3 \%$ in GA group, $p=0.001$, Table 2). $\mathrm{SpO}_{2}$ level did not decrease below 95\% in any patient in any group in any period. Postlumbar puncture headache, urinary retention and PONV have not been observed in any patient.

Table 2. Comparison of side effects between groups.

\begin{tabular}{|c|c|c|c|c|}
\hline & & Group SA & Group GA & $\begin{array}{l}\mathbf{p} \\
\text { Value }\end{array}$ \\
\hline $\begin{array}{l}\text { Surgeon satisfaction } \\
\text { score }\end{array}$ & $\begin{array}{l}\text { Min-Max } \\
\text { (Median) }\end{array}$ & $6-10(9)$ & $8-10$ (9) & ${ }^{\mathrm{a}} 0.623$ \\
\hline $\begin{array}{l}\text { Patient satisfaction } \\
\text { score }\end{array}$ & $\begin{array}{l}\text { Min-Max } \\
\text { (Median) }\end{array}$ & $6-10(10)$ & $3-10(7)$ & ${ }^{\mathrm{a}} 0.001$ * \\
\hline Shoulder Pain (\%) & $\begin{array}{l}\text { YES } \\
\text { NO }\end{array}$ & $\begin{array}{l}21(70.0) \\
9(30.0)\end{array}$ & $\begin{array}{l}30(100) \\
0(0)\end{array}$ & ${ }^{e} 0.002^{*}$ \\
\hline Atropine (\%) & $\begin{array}{l}\text { YES } \\
\text { NO }\end{array}$ & $\begin{array}{l}26(86.7) \\
4(13.3)\end{array}$ & $\begin{array}{l}30(100) \\
0(0)\end{array}$ & ${ }^{\mathrm{e}} 0.112$ \\
\hline Ephedrine (\%) & $\begin{array}{l}\text { YES } \\
\text { NO }\end{array}$ & $\begin{array}{l}15(50.0) \\
15(50.0)\end{array}$ & $\begin{array}{l}0(0) \\
1(3.3)\end{array}$ & b0.001* \\
\hline Urinary retention (\%) & $\begin{array}{l}\text { YES } \\
\text { NO }\end{array}$ & $\begin{array}{l}0(0) \\
30(100)\end{array}$ & $\begin{array}{l}0(0) \\
30(100)\end{array}$ & NS \\
\hline PONV (\%) & $\begin{array}{l}\text { YES } \\
\text { NO }\end{array}$ & $\begin{array}{l}0(0) \\
30(100)\end{array}$ & $\begin{array}{l}0(0) \\
30(100)\end{array}$ & NS \\
\hline
\end{tabular}

"Mann Whitney U test, ' $\mathrm{P}$ earson Chi-Square Test, ${ }^{\mathrm{e}}$ Fisher's Exact Test, " $p<0.05$

Group SA: Group Spinal Anesthesia, Group GA: Group General Anesthesia

PONV: Postoperative Nausea and Vomiting

NS: Nonsignificant

\section{DISCUSSION}

The main finding of this study is that both anesthetic techniques, namely, general and spinal anesthesia, produced effective, comfortable and safe conditions for laparoscopic surgery. Other important result is that in spinal anesthesia group hypotension and bradycardia were observed at a higher rate, although they did not cause any increase in postoperative complication rate or hospital stay. Lower VAS values in early postoperative period in spinal anesthesia group were also important. Shoulder pain was a problem in Group SA, but it was treated properly, and no patient required general anesthesia. Patient satisfaction was higher in the spinal anesthesia group. Surgeons did not mention any difference between groups in terms of surgical satisfaction.

Bradycardia is an expected side effect due to rapid peritoneal stretch and vagal stimulation in laparoscopic cholecystectomy operations ${ }^{8}$. Bradycardia is observed also in spinal anesthesia in most of the cases due to the inhibition of T1-4 cardioaccelerator fibers and decreased right atrial filling. However, studies have reported that this condition can be prevented by fluid replacement and vasopressor addition'. Turkstani et al. reported that $8 \%$ of the spinal anesthesia group had bradycardia requiring atropine injection ${ }^{4}$. We obtained similar results in our study.

Hypotension was reported to occur in $20-30 \%$ of the patients who underwent spinal anesthesia. However, all patients have responded to fluid replacement and single dose vasopressor therapy ${ }^{10-}$ ${ }^{13}$. The decrease in the MAP of more than $30 \%$ in our study may be related to the fact that the intraabdominal pressure $(14 \mathrm{mmHg})$ applied in our study was higher than the intraabdominal pressure (8-10 mmHg) applied in other studies ${ }^{12,14-17}$. Another reason for the higher rate of hypotension in our study may related to higher doses of the drug $^{5,10}$. However, in another study with low dose thoracic spinal anesthesia, durations of motor and 
sensorial block were found to be shorter compare to higher dose used group which may be accepted as an advantage for this type of surgery ${ }^{18}$.

One of the major intraoperative problems of laparoscopic cholecystectomy under spinal anesthesia is right shoulder pain. Previous studies have shown that maintaining intra-abdominal pressure below $10 \mathrm{mmHg}$ reduces right shoulder pain and respiratory distress due to diaphragm irritation ${ }^{19,21}$. In our study, although we routinely applied sedation with midazolam and fentanyl to prevent shoulder pain and restlessness in all patients in Group SA, 30\% of the patients had mild and shortterm right shoulder pain. In one study, 35.5\% of the spinal anesthesia group had right shoulder pain. Of these, $8.9 \%$ had mild and transient shoulder pain, $22.2 \%$ required fentanyl, and $4.4 \%$ had right shoulder pain that did not relieve despite the addition of fentanyl, and caused a transition to general anesthesia ${ }^{11}$. In a study performed with 300 patients laparoscopic surgery was started under spinal anesthesia, and $87.3 \%$ of the patients had right shoulder pain ${ }^{15}$. In $90.03 \%$ of the patients with shoulder pain, the pain was successfully treated with massage, and only $9.93 \%$ of the patients received additional $100 \mathrm{mg}$ tramadol. However, in $0.67 \%$ of the patients, the surgeon switched to general anesthesia. In a retrospective study of 3492 patients who had spinal anesthesia, $12.29 \%$ had shoulder or neck pain. A transition to general anesthesia was required in $0.004 \%$ of the patients despite sedoanalgesia ${ }^{16}$. In our study, intraabdominal pressure $(14 \mathrm{mmHg})$, which may be the reason for the high rate of shoulder pain, was higher than the intraabdominal pressure applied in other studies. However, the pain was mild and disappeared in a short time which we suppose to be related to fentanyl injection, and conversion to general anesthesia due to shoulder pain was not required in any patient.

Although the exact cause of pain after laparoscopic cholecystectomy is still not fully understood, it is more likely to be multifactorial. Abdominal trau- ma during insertion of the trocar, diaphragmatic irritation due to $\mathrm{CO}_{2}$ insufflation, temperature and structure of the insufflated gas, intraabdominal $\mathrm{pH}$, low amount of gas in the peritoneum, intraabdominal trauma during the removal of the gallbladder out of the abdomen, small tears in the parietal peritoneum, abdominal distention and chemical irritation of the peritoneum may be the causes of this pain ${ }^{21-23}$. According to the study by Samer et al. ${ }^{11}$ VAS scores at the $2^{\text {nd }}-4^{\text {th }}$ hours were lower in the spinal anesthesia group compared to the other group. In another study the VAS score at the $6^{\text {th }}$ hour was lower in the spinal anesthesia group, but there was no difference in the VAS scores at the postoperative $12^{\text {th }}$ and $24^{\text {th }}$ hours ${ }^{17}$. In our study, VAS scores were lower in the spinal anesthesia group than the general anesthesia group in the first 4 hours, but no significant difference was found in the subsequent VAS scores. These results are consistent with the literature. However, the $6^{\text {th }}$ hour VAS score has not been investigated, and this may be one of the limitations of our study.

The time of discharge was reported to be shorter in spinal anesthesia patients, in previous studies in general, than the general anesthesia group patients ${ }^{4,12,13}$. In our study all of the patients were discharged on the $1^{\text {st }}$ day postoperatively. In fact, the patients with spinal anesthesia were allowed to be discharged earlier but they were kept in the hospital for 24 hours for surgical considerations.

Patient satisfaction is an important factor for making decision about the type of anesthesia to be performed. In a previous study patients in the spinal anesthesia group were reported to be largely satisfied with the technique of anesthesia. In the same study 26 patients from the general anesthesia group reported a high degree of satisfaction, and 3 reported that they were reasonably satisfied $^{12}$. These results are similar to the results of our study for the Group SA. Higher VAS scores in the early postoperative period may be responsible from this lower satisfaction rate. 
The surgical satisfaction scores were similar in groups in our study. In a previous study, surgical conditions and muscle relaxation were evaluated as bad (1), good (2) and excellent (3) by surgeons, and the mean surgical satisfaction was reported as 2.4 points for both groups ${ }^{3}$. In the studies performed the surgeons also stated that there was good muscle relaxation in spinal anesthesia technique, any technical problems were not encountered and the results were similar in the general anesthesia and the spinal anesthesia groups ${ }^{24}$. These results are similar to the results obtained in our study, and suggest that spinal anesthesia is a good alternative to general anesthesia for laparoscopic cholecystectomy.

One of the limitations of our study is the high intraabdominal pressure created during pneumoperitoneum. This affected hemodynamic values negatively, and contributed to the occurrence of shoulder pain. Imbelloni et al. worked under pressure of $8 \mathrm{mmHg}$, and applied intraperitoneal local anesthetic when patients felt pain. In this way, they reduced the rate of shoulder pain by $47 \%$ to $20 \%{ }^{18}$. However, it should be kept in mind that low pneumoperiteneum pressure may lead to limited surgical vision.

\section{CONCLUSION}

According to the results of this clinical prospective study it may be concluded that spinal anesthesia may be used as an alternative method to general anesthesia in patients undergoing laparoscopic cholecystectomy, especially when the risk of general anesthesia is too high in patients with a predetermined difficult intubation, severe respiratory disease or history of malignant hyperthermia.

\section{REFERENCES}

1. Cunningham AJ, Brull SJ. Laparoscopic cholecystectomy: anesthetic implications. Anesth Analg. 1993;76:112033. [CrossRef]

2. Bajwa SJ, Kulshrestha A. Anaesthesia for laparoscopic surgery: General vs regional anaesthesia. J Minim Access Surg. 2016;12:4-9. [CrossRef]
3. Kalaivani V, Vinayak SP, Sreevathsa MR, Bharati VH, Bevinaguddaiah Y. Laparoscopic cholecystectomy under spinal anaesthesia vs. general anaesthesia: A prospective randomised study. J Clin Diagn Res. 2014;8(8):NC01-4. [CrossRef]

4. Turkstani A, Ibraheim O, Khairy G, Alseif A, Khalil N. Spinal versus general anesthesia for laparoscopic cholecystectomy a comparative study of cost effectiveness and side effects. Anaesth Pain \& Intensive Care 2009;13: 9-14.

5. Yu G, Wen Q, Qiu L, Bo L, Yu J. Laparoscopic cholecystectomy under spinal anaesthesia vs. general anaesthesia: a meta-analysis of randomized controlled trials. BMC Anesthesiol. 2015;15:176. [CrossRef]

6. Wang XX, Zhou Q, Pan DB, et al. Comparison of Postoperative Events between Spinal Anesthesia and General Anesthesia in Laparoscopic Cholecystectomy: A Systemic Review and Meta-Analysis of Randomized Controlled Trials. Biomed Res Int. 2016;2016:9480539. [CrossRef]

7. Ciofolo MJ, Clergue F, Seebacher J, Lefebvre G, Viars P. Ventilatory effects of laparoscopy under epidural anesthesia. Anesth Analg. 1990;70:357-61. [CrossRef]

8. Myles PS. Bradyarrhythmias and laparoscopy: a prospective study of heart rate changes with laparoscopy. Aust N Z J Obstet Gynaecol. 1991;31:171-3. [CrossRef]

9. Longo MA, Cavalheiro BT, de Oliveira Filho GR. Laparoscopic cholecystectomy under neuraxial anesthesia compared with general anesthesia: Systematic review and meta-analyses. J Clin Anesth. 2017;41:48-54. [CrossRef]

10. Mehta PJ, Chavda HR, Wadhwana AP, Porecha MM. Comparative analysis of spinal versus general anesthesia for laparoscopic cholecystectomy: A controlled, prospective, randomized trial. Anesth Essays Res. 2010 JulDec;4(2):91-5. [CrossRef]

11. Bessa SS, Katri KM, Abdel-Salam WN, El-Kayal el-SA, Tawfik TA. Spinal versus general anesthesia for day-case laparoscopic cholecystectomy: a prospective randomized study. J Laparoendosc Adv Surg Tech A. 2012;22:550-5. [CrossRef]

12. Imbelloni LE, Fornasari M, Fialho JC, Sant'Anna R, Cordeiro JA. General anesthesia versus spinal anesthesia for laparoscopic cholecystectomy. Rev Bras Anestesiol. 2010;60:217-27. [CrossRef]

13. Tzovaras G, Fafoulakis F, Pratsas K, Georgopoulou S, Stamatiou G, Hatzitheofilou C. Spinal vs general anesthesia for laparoscopic cholecystectomy: interim analysis of a controlled randomized trial. Arch Surg. 2008;143:497501. [CrossRef]

14. Bessa SS, El-Sayes IA, El-Saiedi MK, Abdel-Baki NA, Abdel-Maksoud MM. Laparoscopic cholecystectomy under spinal versus general anesthesia: a prospective, randomized study. J Laparoendosc Adv Surg Tech A. 2010;20:515-20. [CrossRef]

15. Kar M, Kar JK, Debnath B. Experience of laparoscopic cholecystectomy under spinal anesthesia with low-pressure pneumoperitoneum--prospective study of 300 cases. Saudi J Gastroenterol. 2011;17:203-7. [CrossRef]

16. Sinha R, Gurwara AK, Gupta SC. Laparoscopic cholecystectomy under spinal anesthesia: a study of 3492 patients. J Laparoendosc Adv Surg Tech A. 2009;19:323-7. [CrossRef]

17. Tiwari S, Chauhan A, Chaterjee P, Alam MT. Laparoscopic cholecystectomy under spinal anaesthesia: A prospective, randomised study. J Minim Access Surg. 2013;9:65- 


\section{1. [CrossRef]}

18. Imbelloni LE, Sant'anna R, Fornasari M, Fialho JC. Laparoscopic cholecystectomy under spinal anesthesia: comparative study between conventional-dose and low-dose hyperbaric bupivacaine. Local Reg Anesth. 2011;4:41-6. [CrossRef]

19. Hamad MA, El-Khattary OA. Laparoscopic cholecystectomy under spinal anesthesia with nitrous oxide pneumoperitoneum: a feasibility study. Surg Endosc. 2003; 17:1426-8. [CrossRef]

20. Sarli L, Costi R, Sansebastiano G, Trivelli M, Roncoroni L. Prospective randomized trial of low-pressure pneumoperitoneum for reduction of shoulder-tip pain following laparoscopy. Br J Surg. 2000;87:1161-5. [CrossRef]
21. Kehlet $\mathrm{H}$. Effect of postoperative pain treatment on outcome-current status and future strategies. Langenbecks Arch Surg. 2004;389:244-9. [CrossRef]

22. Lee IO, Kim SH, Kong $M$ H, et al. Pain after laparoscopic cholecystectomy: the effect and timing of incisional and intraperitoneal bupivacaine. Can J Anaesth. 2001;48:54550. [CrossRef]

23. Luchetti M, Palomba R, Sica G, Massa G, Tufano R. Effectiveness and safety of combined epidural and general anesthesia for laparoscopic cholecystectomy. Reg Anesth. 1996;21:465-9.

24. Yuksek YN, Akat AZ, Gozalan U, et al. Laparoscopic cholecystectomy under spinal anesthesia. Am J Surg. 2008;195:533-6. [CrossRef] 